\title{
Pragmatism, Holism, and the Concept of Law
}

\author{
Adam Michał Dyrda*
}

\begin{abstract}
When discussing O. W. Holmes's answer to the question What constitutes the law? Morton White underlines the fact that Holmes's inquiry didn't focus on developing the concept of law. White states: '.... Holmes said little in The Path of the Law about the notion of legal authority, perhaps because he was interested not in what he called a "useless quintessence of all legal systems" but in "an accurate anatomy of one"'. Such ambition (or lack of ambition) is characteristic of many pragmatic enterprises in the field of jurisprudence. However, sometimes the opposition between legal pragmatism and other legal theories is built upon a reference to the notion of the 'nature' or 'essence' of law. Many legal philosophers who aim to reveal the very 'nature of law' (or 'the concept of law' as H. L. A. Hart did) try to interpret Holmes and other pragmatists as offering a competitive view to their own. I will follow White's early intuition that such a construal of the controversy is simply wrong. Afterwards I will sketch a portrait of legal pragmatism in the context of White's own inquiry and his version of 'holistic pragmatism'; thirdly, I will present in brief the main reasons for exploring the concept of law in the contemporary analytic philosophy of law. Then I will show that traditionally 'pragmatic' and 'analytic' efforts in legal theory are situated on different levels of generality and conceptuality. However, these efforts can be, at least to some extent, reordered under the aegis of holistic pragmatism.
\end{abstract}

Keywords: legal pragmatism, holistic pragmatism, O.W. Holmes, H.L.A. Hart, M.G. White

\section{The Methodological Objection}

One of the most important matters in science and philosophy is the way in which we formulate questions; hence, the object of inquiry is, at least to some extent, implicitly suggested in every preliminary question asked. Thus, probably one of the most important (and,

Adjunct Professor, Department of Legal Theory, Faculty of Law, JagielIonian University, Cracow, Poland. Contact: adam.dyrda@uj.edu.pl; http://jagiellonian.academia.edu/AdamDyrda. I'm grateful to the organizers and the participants of the workshop on legal pragmatism at the IVR World Congress in Belo Horizonte (July 2013, Brazil) for their comments and discussion over the main ideas included in the very preliminary draft of this article. I owe special thanks to two anonymous referees who pointed out at least the most clamant shortcomings of this article. equally, most commonplace) accusations against a certain legal theory is the 'methodological objection' (MO). In its general form, it is as follows:

(MO) The discussed theory fails because it uses the wrong methodology and asks the wrong questions, which precludes the theory from reaching the right (adequate) conclusions. Without putting our questions in the right way, we cannot grasp any substantial answers, i.e. such answers that (at least) could have a claim to adequacy. ${ }^{1}$

It seems, then, that for researchers who use this argument against a particular theory $\mathrm{T}$, the theory $\mathrm{T}$ fails on its own grounds because it asks the wrong questions and, thus, receives inadequate answers. However, it is important not to simply equate inadequate answers with false answers. It may well be that the explanations proposed by $\mathrm{T}$ are true, but nevertheless, these truths can be assessed as falling beyond the 'real interest' of the particular (legal) theory. Therefore, even true theoretical answers can be inadequate in the sense that they are answers to the 'wrong questions' (and thus irrelevant) or even that they are the answers to questions that have actually never been asked (or need not have been asked)! To say 'Sorry, but you missed the important methodological point' is to claim that the whole theoretical effort made in order to answer questions has been useless. For sure, there is nothing more frustrating for a theorist than to hear something like that!

In such circumstances, theory $\mathrm{T}$ may be true, but nevertheless, it would not be a theory of the right sort. To put it in another way, it would not be the theory of the thing that it pretends to be the theory of. The label is wrong; therefore, after the successful conduct of the MO, theory $\mathrm{T}$ is compromised.

The methodological objection is a very popular critical move and probably the one that allows individuals to undermine a theory at the very beginning, without making any deeper research about its content. On the other hand, if the basic questions are, in the eyes of a critic, put rightly, she/he has to examine a substantial part of the theory more thoroughly. However, the answers giv-

1. Generally speaking, 'adequate claims' are ontic characteristics of things that are neither too narrow (and thus lacking some element or explanation) nor too vast (where characterisation is replete with elements that are unnecessary to properly describe or explain a thing). According to that definition, $\mathrm{MO}$ is primarily designed against descriptive-explanatory theories. In case of normative-evaluative theories, MO can be used only partially to discredit descriptive assumptions of such theory (on the basis that these assumptions are not the assumptions of the right kind). It is however hard to imagine how $\mathrm{MO}$ could be applied against purely normative theories (if there are any). 
en by a particular theory could not ever be conceived as irrevocable, solid, final answers. Any possibility of reaching Peirce's "Final Opinion" shall be rather conceived as an ideal, and thus, we are allowed to give only preliminary answers, which surely would not be perfectly, ideally adequate, but may appear to be practically adequate in the sense that they would stand as sufficient reasons to formulate answers, despite the awareness of their potential incompleteness. And such answers would not only be of theoretical but also of practical importance.

Let us say that a 'human' theory should aim at giving answers in the most intuitive, practical sense (attempting to reach the possible, practical optimum) - answers that could be understood and rationally discussed by different parties. As C. S. Peirce stated, the main task of any inquiry or investigation is 'the settlement of (true) opinion' about reality, though humans might fail to reach the ultimate opinion on any question 'as long as the human race should last'. ${ }^{2}$ A 'true belief' in such a scheme is a temporary, 'calm and satisfactory state' attained when the irritation and the doubt have been removed. The more practical a belief is, the more it becomes a longer and a more comfortable stop on our way to the ultimate true opinion (that would probably never be achieved).

In the following sections, I want to deal with particular, uncharitable criticisms of legal pragmatism. On that ground, there arises a question about the method of conceptual analysis applied by legal pragmatists. Having answered this question, I can focus on the holistic pragmatism understood as a general, philosophical background for differing and prima facie inconsistent conceptions of law.

\section{How Does the Critique Usually Go?}

The first thing I would like to focus on is the way the critique of non-pragmatist thinkers against legal pragmatism usually goes. There are actually a few ways to defy legal pragmatism. The first one is to undermine its philosophical background as, in the least, inaccurate. One must be perfectly acquainted with the philosophy of pragmatism to follow that line of thought. In fact, critics are often only generally aware of what such thinkers as W. James, C. S. Peirce, G. H. Mead, J. Dewey, and others have said on the matter. Such critics use maxims and epigrams rather than arguments and do not care whether their own interpretations fulfil the socalled charity principle. That is why the history of the critique of philosophical pragmatism (and its counterparts like legal pragmatism) is a story of misinterpretations. Significantly, W. James observed a long time ago

2. C.S. Peirce, How to Make Our Ideas Clear? (1878), access online: $<$ www.marxists.org/reference/subject/philosophy/works/us/peirce. $\mathrm{htm}>$. that such situations were 'nothing new' ${ }^{3}$ This observation remains true.

D. Lind has recently pointed out that some authors, like R. Dworkin, D. Luban, P. S. Atiyah, and B. Z. Tamanaha, attempt to undermine legal pragmatism by saying that it is 'amorphous', 'antitheoretical', and 'skeptical jurisprudence', one that 'languishes in indeterminacy, depreciates the instinctive structure of legal reasoning and decision making, and commits a host of other jurisprudential sins'. ${ }^{4}$ Probably the most important reason for such a labeling of legal pragmatism is that it is viewed as 'result oriented or instrumental', where adherence to precedent and rules is only contingent and not based on principle, as far as making a decision is always 'instrumentally important' for a community. ${ }^{5}$ In a similar way, R. Dworkin argues that pragmatism supports an approach to adjudication that 'holds that judges should always decide the cases before them in a forward-looking consequentialist style', ${ }^{6}$ and thus, he 'sees pragmatism as a worrisome interpretive conception of law that sacrifices principle and integrity for whatever outcomes would seem to be "best for the future without concern for the past". ${ }^{7}$ I am not going to repeat Lind's way of defending legal pragmatism against these accusations here. I will limit myself only to notice that his way of argument reinterprets the misunderstood claims of legal pragmatists like O. W. Holmes and B. Cardozo in the light of certain background philosophical assumptions. Thus, he simply shows that 'result orientation', 'instrumentalism', 'antitheoretical character', and so on are not exactly what these critics think them to be. ${ }^{8}$ Quite a similar strategy of defence was developed by $\mathrm{S}$. Haack who presented the interpretation of Holmes's position in the philosophico-historical context of its origin. ${ }^{9}$ In such cases as these, the conclusion of the whole analysis is that the critics have simply misunderstood what is at stake with pragmatism.

Unfortunately, the approach consisting of criticising philosophical pragmatism (both as a general movement and as a theory of a particular thinker) from an expert's point of view, and subsequently falsifying claims of legal pragmatism on the basis of such a ('charitable') critique,

W. James, Pragmatism: A New Name for Some Old Ways of Thinking (1907), Lecture I.

4. D. Lind, 'The Mismeasurement of Legal Pragmatism', 4 (2) Washington University Jurisprudence Review 213, at 213-4 (2012).

5. D. Luban, 'What's Pragmatic about Legal Pragmatism?,' 18 Cardozo Law Review 43 (1996).

6. R. Dworkin, Justice in Robes (2006), at 21.

7. Lind (2012), above n. 4, at 215; cf. R. Dworkin, Law's Empire (1986), at 151.

8. In one of my articles I call these critics "Momosian critics", derived from the name Momos, a Greek god of evil-spirited blame and unfair criticism (and not a 'momos' as a dumpling!). See A. Dyrda, 'Momosa pragmatyzm prawny: rzeczywiste granice teorii, rozsądne granice krytyki, 2 Jurysprudencia (special volume: 'Integracja zewnętrzna i wewnętrzna nauk prawnych, cz.1')['Internal and External Integration of Jurisprudence, part 1'] 149 (2014).

9. S. Haack, 'On Legal Pragmatism: Where Does "The Path of the Law" Lead Us?', 50 American Journal of Jurisprudence, 71 (2005). 
is rather rare. Usually ${ }^{10}$ the objection takes the following direction. As indicated above (in the case of Dworkin and Luban), one says that legal pragmatism is simply wrong, as it misses the point of legal theorising, that is, a careful analysis of basic legal concepts (this is a version of the MO argument), which would eventually reveal the true 'nature' of law (a kind of 'substantial argument'). By making such statements, critics try to present substantial arguments, as well as the MO against legal pragmatism, usually without any deeper knowledge of legal pragmatism's rationale, namely, its philosophical foundations and its proper methodology. In the above-mentioned critiques, especially of Luban and Dworkin, the MO argument and substantial arguments are mixed together (and they are surely linked: substantial claims are strictly related to the assumed methodological theses, because, I suppose, assumed methodology circumscribes the scope of possible questions and limits, or otherwise underdetermines, a possible understanding of a theory ${ }^{11}$. Lind tries to defend legal pragmatism by showing that substantial points have been misunderstood by the critics, which eventually shows that the methodological stance of these thinkers towards legal pragmatism is wrong. Such a way of defending legal pragmatism is fair but, to my mind, also too extensive and wearisome. I think that it is much easier to formulate the argument against prejudiced critics the other way around, i.e. firstly, to describe the basic methodological stance of legal pragmatism and then, secondly, to compare it with the methodology assumed by critics. Such an argument would be more beneficial and universal, since it could be used not only against certain methods of critiquing (that are based, amongst others, on substantial arguments) but against all theories that seem to reach different substantial claims by assuming (at least prima facie) quite different methodologies. This way of arguing is, to some extent, implicit in what $\mathrm{S}$. Haack or B. Leiter has been writing recently on legal pragmatism (realism). ${ }^{12}$ This would also allow us to show, by detailed analysis of theories compared, that a clarification of present misunderstandings can also lead to reconcile them (which were at first glance so different).

The pivotal problem is as follows: what is the meaning of conceptual analysis or concept explanation in legal pragmatism and other theories of law? Moreover, does legal pragmatism seek what all the apostles of general

10. There are also serious critics of legal pragmatism who are not subject to my argument. I think that they are 'serious' to a large extent because they accept, at least provisionally, the holistic account I present in the following section.

11. S. Perry rightly notices: 'Because jurisprudence lies within a rather unstable area of intersection between philosophy and social theory, methodological questions tend to be as controverted as substantive questions, and often two become inextricably entangled' (S. Perry 'Holmes v. Hart: The Bad Man in Legal Theory', in S. Burton (ed.), The Path of The Law and Its Influence: The Legacy of Oliver Wendell Holmes, Jr. (2000) 158, at 160.

12. Cf. Haack (2005), above n. 9; B. Leiter, 'Legal Realism and Legal Positivism Reconsidered', 111(2) Ethics 278 (2001). jurisprudence ${ }^{13}$ try to find: the 'essence', the 'nature', and the 'concept of law'? The answer is surely negative, but critics (usually, but not always, apostles of analytical, general jurisprudence) wrongly assume that legal pragmatism attempts to answer such questions, and much of their writings (Hart's argument against legal realism is a prime example here) are devoted to showing that legal pragmatism is an inadequate theory of law just because it cannot solve definitely general, conceptual questions which would eventually trigger essentialist answers (although I think that the general 'essentialist objection' ${ }^{14}$ against all general-jurisprudential efforts is not valid in each and every case). The situation in which legal pragmatism, notably represented by Holmes or Cardozo, is placed by uncharitable critics resembles the way in which the philosophical pragmatism of James, for instance, was criticised by G. E. Moore and B. Russell, who actually thought that James had been trying to elaborate on 'truth' as a concept (and was willing to propose a synonym for the word 'truth'), whereas, on the

13. I'm thinking of the general, analytical jurisprudence in a wider sense, including not only H.L.A. Hart and his descendants, but R. Dworkin and his followers as well - i.e. the sense in which the one, abstract relation between important legal concepts is supposed be established by a theory. S. Perry uses in this context the term 'comprehensive theory of law' (Perry, above n. 11). The relation between 'essence' (understood as necessary and sufficient feature of being such-and-such, wider than essence, covering also typical but not necessary features of an object) and "concept" (the most general term) is a mater of persistent controversy. It is not clear what the task of general jurisprudence is. Is it the explanation of the concept of law? Or maybe it is the inquiry into the very nature or even essence of law? Hart's basic project can be understood to large extent as anti-essentialist, for Hart, in the first chapter of The Concept of Law does not want to provide the real definition of law in its classical form (genus proximum + differentia specifica). Such interpretation is presented for example by F. Schauer. It is not clear, however, whether Hart's position precludes from providing other, more complicated forms of real definition of law, the more that providing such a definition does not amount merely to present a semantic equivalent (and thus Dworkin's famous semantic sting argument does not apply here). So, even if we accept the 'anti-essentialist' interpretation of Hart's enterprise in the simplest meaning of that that term (cf. F. Schauer, 'Hart's Anti-Essentialism', in A. Dolcetti, L. Duarte d'Almeida \& J. Edwards (eds.), Reading H.L.A. Hart's 'The Concept of Law' (2013), 237, there is still much place for more detailed conceptual work to be done within his account in generally essentialist spirit. The question asked by Hart is 'what is law?' and this is a purely metaphysical question. Whether the answer refers to the idea of law's 'essence', 'nature' or 'concept', in each case answer would at least imply some kind of metaphysical solution. Basing on that intuition, pervasive in post-Hartian general jurisprudence, J. Raz wrote: 'In as much as a general theory of law is about the nature of law it strives to elucidate law's essential features, i.e., those features which are possessed by every legal system just in virtue of its being legal, by every legislative institution in virtue of being legislative, by every practice of legal reasoning in virtue of its being a practice of legal reasoning, and so on. A claim of necessity is the nature of the enterprise' (J. Raz 'On the Nature of Law', in J. Raz (ed.), Between Authority and Interpretation: On the Theory of Law and Practical Reason (2009) 91, at 92. In case of Dworkin, although he himself claims that the 'nature' of law is nothing more than 'conforming mantra, positivism's phlogiston' (R. Dworkin, Justice in Robes (2006), at 216), in his well known argumentation he continually refers to 'true proposition of law' and 'grounds of law', what at least conceptually presupposes that such grounds exists (and this a metaphysical thesis as well; in case of Dworkin such thesis is supported by a peculiar version of moral realism). In this sense contemporary general jurisprudence shares the basic tenets of Langdellism and Begriffiurisprudenz.

14. Haack (2005), above n. 9 
contrary, James 'saw himself as an inquirer into the motives of $[\ldots]$ truth-claimers, an inquirer into the causes of beliefs, just as he saw himself as an inquirer into the sources or causes of religious feelings in the Varieties' ${ }^{15}$ The assumption that Holmes and other legal pragmatists tried to answer the same questions about law that analytic legal philosophers habitually ask has led critics like Hart or Dworkin completely astray. Just as James was not concerned with finding a synonym for 'truth', Holmes was not interested in presenting the analysis of the concept of law (the 'nature' of law, as J. Raz would put it), with all the abstract and general characteristics it was supposed to have. I think that many of the contemporary analyses of legal pragmatism, ${ }^{16}$ including comparisons with other theories, are inquisitive enough to see what is at stake with such critics. However, this case is not new. In fact, one of the most influential thinkers who put forward that legal pragmatism is not the kind of 'conceptual theory' the critics expect it to be was M. G. White.

In the subsequent parts of the paper, I will discern the general view which encompasses the important philosophical background for pragmatism as a whole, namely, White's 'holistic pragmatism'. Then, by application of this philosophical stance to legal theory (by a quick analysis of an interesting example of $\mathrm{O}$. W. Holmes's approach), I will present in a nutshell the difference between the pragmatic concept explanation and the methodology of concept analysis assumed by major figures of general (conceptual) jurisprudence. In effect, the thesis that the 'cynical' but poetical answers that Holmes and his pragmatist followers give to important jurisprudential questions are to some extent 'independent' from any metaphysical or essentialist conceptions of law (like legal positivism, law as integrity, etc. $)^{17}$ nevertheless does not mean that they are not (or could not be) eventually underdetermined by some general jurisprudential conceptions. This will show that the MO argument against legal pragmatism from the generaljurisprudence position (that sometimes reminds a 'trench warfare') is not a valid one. Unless a critic embraces strong metaphysical assumptions about law, her analysis of the concept of law would be coherent with holistically underdetermined general theory of law (like legal positivism). In other words, if a legal theorist

15. M.G. White, The Philosophy of Culture: The Scope of Holistic Pragmatism (2002), at 22; cf. S. Pihlström, 'Morton White's Philosophy of Culture: Holistic Pragmatism and Interdisciplinary Inquiry', 21 Human Affairs 140 (2011), at 146

16. Leiter (2001), above n. 12; Haack (2005), above n. 9.

17. Pragmatists' anti-essentialism expresses the thesis that the way we think about things we want to describe (the way we weave the web of belief) determines our conception of these things. In this sense, there is no metaphysical necessity involved in analysis (I deliberately put aside the problem of epistemic necessity). On the other hand, the broadly conceived essentialism proclaims the thesis that there is something necessary we can say about things like law, even if in result of performed analysis we get, for example, a cluster of minor concepts. If a theorist thinks that there is a solid truth-maker for 'propositions of law' (like the one established by the rule of recognition, either inclusive or exclusive), then a theorist is an essentialist and a metaphysician, at least in a broad sense. at least remains skeptical in connection with basic metaphysical assumptions about reality, including 'the nature of law', legal pragmatism and some particular types of conceptual, general theory of law can simply coexist. In this sense, these two differing positions can be reconciled.

\section{Holistic Pragmatism and Law}

M. G. White indicates that 'holistic pragmatism' is the view developed in W. V. Quine's masterpiece Tmo Dogmas of Empiricism, where he wrote: 'Each man is given a scientific heritage plus a continuing barrage of sensory stimulation; and the considerations which guide him in warping his scientific heritage to fit his continuing sensory prompting are, where rational, pragmatic' ${ }^{18}$ Four elements are characteristic of that view: ${ }^{19}$ (1) this view is about the behaviour of human beings and their heritage (some cultural phenomena); (2) a scientific heritage is understood as a conjunction of many beliefs rather than as one non-conjunctive belief, what eventually leads to the claim that that our beliefs (or sentences) are not tested individually but 'face the tribunal of experience' in corporate bodies ('holism'); ${ }^{20}$ (3) there is the reference to a barrage or sensory stimulation or a flux of experience ('empiricism'); and (4) there is the reference to the pragmatic warping of a scientific heritage that has to fit sensory promptings ('pragmatism'). As White writes: 'According to holistic pragmatism, scientists' warpings are carried out with concern for the elegance or simplicity of the theory they adopt and with the intention to warp the heritage conservatively', ${ }^{21}$ thus engaging 'minimum modification' (James) or 'minimum mutilation' (W. V. Quine) of it. ${ }^{22}$ Being as it is, the holistic pragmatism is primarily opposed to classical rationalism (the view that we can have knowledge that is not tested by experience; in its contemporary form espoused by Descartes). Moreover, in pure versions of holistic pragmatism, the dualism between 'the analytic' and 'the synthetic', to some extent accepted by some pre-pragmatist thinkers (like Hume's distinction between 'experimental thinking' and 'abstract thinking'), as well as some classical pragmatists (according to White, neither W. James nor J. Dewey fully escaped from this dichotomy), is abandoned. The theory, being a conjunction of different kinds of statements (logical, empirical), must fit the sensory promptings, and if we want to make this relation of 'fitting of belief' work, sometimes even some logical

18. W.V. Quine 'Two Dogmas of Empiricism', in W.V. Quine, From a Logical Point of View: Nine Logico-Philosophical Essays (1953) 20, at 46.

19. White (2002), above n. 15, at 1

20. Cf. Pihlström (2011), above n. 15, at 141

21. White (2002), above n. 15, at 2.

22. W. James, Pluralism, Pragmatism and Instrumental Truth (1907), 52, above n. 3, at 61, where James writes about 'minimum of modification' (online: <www.uky.edu/ eushe2/Pajares/jpluralism.html>); cf. Quine (1953). Arguments against this pragmatic theory of belief revision see H. Rott, 'Two Dogmas of Belief Revision', internet access <www.lucs.lu. se//spinning/categories/dynamics/Rott/Rott.pdf>. 
statements - or according to legal positivists 'analytic truths' - should be rejected. That stays in close connection with an abandoning of 'the spectator's view' in all fields of inquiry - scientific, moral, legal, and artistic, which are all equal subfields of cultural philosophy (being actually a metaphilosophical position) ${ }^{23}$. However, the difference between statements characteristic of each subdiscipline is not, as Quine ultimately thought, different in kind, but only, according to White, different in degree. ${ }^{24}$

M. G. White, inspired not only by Quine but also by J. Dewey ('epistemological gradualism') and A. Tarski ('epistemological holism'), extended the restrictive view that Quine held himself, namely, the view that 'the philosophy of science is philosophy enough'. Quine's line of argument was strictly connected with his idea of 'naturalised epistemology'. Such a remnant of logical positivism as 'rationalism', against which Quine argued in his article, ${ }^{25}$ should be replaced by the fully fledged holistic pragmatism, according to which 'the philosophy of culture is philosophy enough'. In this view, science is only one of many cultural institutions that are interesting for philosophers (once Quine himself compared science to the Wittgenstein's language game: 'the game of science $\left.{ }^{26}\right)$. And these institutions should be described, analysed, or explored on equal rights. According to White, 'we may distinguish different disciplines associated with various elements of culture on the basis of their different vocabularies and substantive statements, but not by saying that we use fundamentally different methods in supporting those statements'. ${ }^{27}$ All of these disciplines - ethics, law, art, and science - are 'anchored in experience', and all of them are corrigible but cognitive enterprises, which eventually form altogether a 'holistic totality' instead of 'any compartmentalised group of distinct areas with definite boundaries' ${ }^{28}$ To put it in a slightly different manner, in science, morality, art, and law, we use the same empirical method requiring 'an examination of how we do and should use language'. That is not an effort characteristic of rationalists or certain significant twentieth-century thinkers (B. Russell, G. E. Moore, C. I. Lewis, R. Carnap) for decomposing concepts. White assesses the rational

23. As H. Putnam, a disciple of $M$. White, recognises, the abandonment of 'the spectator's view', that Quine, Goodman, or Davidson themselves postulate, would mean nothing 'if we don't extend the pragmatic approach to the most indispensable "versions" of ourselves and our world that we possess' (H. Putnam, The Many Faces of Realism (1987), at 21; cf. Pihlström, above n. 15, at 141).

24. White (2002), above n. 15, at 154-5.

25. Quine (1953), above n. 18.

26. Quine wrote: '... [W] [Wen I cite predictions as the checkpoints of science, I do not see that as normative. I see it as defining a particular language game, in Wittgenstein's phrase: the game of science, in contrast to other good language games such as fiction and poetry. A sentence's claim to scientific status rests on what it contributes to a theory whose checkpoints are in prediction' (W.V. Quine, Pursuit of Truth (1990, at 20; cf. M. Murphey, The Development of Quine's Philosophy (2012), at 241; cf. D.G. Windblad, 'Scepticism, Science, Quine and Wittgenstein,' in R. Arrington, H-J. Glock (eds.), Wittgenstein and Quine 97 (1996).

27. White (2002), above n. 15, at 3.

28. Pihlström (2011), above n. 15, at 143. methods of analysis, due to the failure of the analyticsynthetic distinction and the paradox of analysis, as unfruitful. On the contrary, the holistic program is a struggle against apriorism connected with various forms of rationalism, and, for sure, holistic pragmatists appreciate the strength of their rationalistic foes. In 1877, C. $\mathrm{S}$. Peirce wrote that the rationalistic, a priori method was the most intellectual and respectable of all the old methods. He also pointed out: 'its failure has been the most manifest' ${ }^{29}$ Holistic pragmatism elaborates against any ultimate rationalisation, or what Dewey once called 'the quest for certainty', that reminds us of the most important point: both in science par excellence and in 'soft sciences' (law, art, ethics), there are no ready-made solutions in advance of particular problems.

It is, however, important to stress that holistic pragmatism ought to be conceived as a rule (a normative stance) rather than a descriptive statement. ${ }^{30}$ It is the method of testing our beliefs, being, in fact, a normative method of how one should philosophise (metaphilosophy), being neither analytic, a priori, necessary, nor self-evident. It is rather 'our best guess so far' that should be followed 'in a fallibilist spirit'. ${ }^{31}$

In the field of law, holistic pragmatism can be found in W. James's Pragmatism, ${ }^{32}$ where he wrote 'given previous law and a novel case...the judge will twist them into fresh law' which - as White notices - reflects the demeanor of a scientist who begins with a conjunction of previous truths, encounters fresh facts, and incorporates fresh truths or revises the old' ${ }^{33}$ It is quite interesting that just a decade before James wrote this, $\mathrm{O}$. W. Holmes had delivered his famous speech 'The Path of the Law'. This speech is a great source of immortal epigrams, either expressing his antirationalist position ('The life of the law has not been logic, it has been experience') or his, as simple as it is controversial, answer to the question: What consitutes the lam? ('The prophecies of what the courts will do in fact, and nothing more pretentious, are what I mean by the law').

Holmes's lecture, as we know, focused on the approach of an operative lawyer who is bound to present to a billpaying client the best possible prediction of the judicial decision. As a heuristic position, using some kind of binoculars through which the lawyer tries to formulate a prediction of the decision (like an analyst who tries to forecast weather), Holmes presents the 'bad man's point of view', who does not care 'a straw' about rules and precedents, but simply wants to be kept out of jail (and thus he must anticipate the future judicial decree). Many objections have been raised against this conception. One of the most influential was the critique devel-

29. C.S. Peirce, The Fixation of Belief (1877), online access: <www.peirce. org/writings/p107.html>.

30. White (2002), above n. 15, ch. XI; cf. Pihlström (2011), above n. 15, at 143.

31. Therefore, it should be possible to critically evaluate or test holistic pragmatism by use of holistic pragmatism (cf. Pihlström, above n. 15, at 143).

32. James, above n. 3, Lecture VII.

33. White (2002), above n. 15, at 126. 
oped by H. L. A. Hart, who noticed that, firstly, law cannot be perceived as consisting only of predictions, and secondly, we should not always regard the lawyer's client as a bad man only. Hart's effort in a few passages in The Concept of Lam was to show that Holmes's legal realism is wrong due to the fact that there really exists something that falls under the concept of 'legal obligation' (or, more generally, the concept of 'legality'). Hart wrote: 'that a person has a legal obligation to do something does not mean the same as saying that he will be punished if he does not perform that act'; ${ }^{34}$ or 'the statement that a rule is [legally] valid is an internal statement recognising that the rule satisfies the test for identifying what is to count as law [...], and constitutes not a prophecy of but a part of the reason for the decision'. ${ }^{35}$ These citations are only two excerpts from the long and still strong methodological objection made by Hart against different forms of legal pragmatism (realism) generally. ${ }^{36}$ As B. Leiter recognises, Hart criticises legal pragmatists by attaching to them a label of 'conceptual rule skepticism', namely, an account according to which 'it is impossible to articulate a simple idea that the law is one thing, and a particular court's decision another'.37

It seems that all we have here is the popular and controversial theory of 'a bad man' here. But it would be a mistake to equate this theory, actually a very parochial (local) one, with the kind of overall philosophical view about law that Holmes held. I think that we can distinguish at least two other, but somehow interconnected, parochial theories in Holmes's thinking and also one more general conception under which, to some extent, all the three parochial theories fall together. And that general approach would have much to do with holistic pragmatism; being the methodological stance, he embraced to propose any, either local or more general, claims about law (although Holmes himself did not use the term 'pragmatism' to describe his own philosophy, and, moreover, he was quite critical of pragmatic philosophy in general, apart from some works of J. Dewey). ${ }^{38}$ Nowadays, it is quite clear that the 'predictive theory' is not a descriptive theory of judicial behaviour, i.e. a naturalistic theory of adjudication, just because it refers to the reasons and facts upon which an operative lawyer builds his prediction. The descriptive theory of adjudication rather should refer to the facts, rules, reasons,

34. H.L.A. Hart, The Concept of Law (1994), at 82.

35. Hart (1994), above n. 34, at 105.

36. As to the relations between legal pragmatism and legal realism, I think that realism is an important but not the only possible upshot of pragmatism. In the case of Holmes's 'bad man', we can speak interchangeably about 'realism' and 'pragmatism', but there are also other less realistic elements of Holmes's pragmatic overview.

37. Leiter (2001), above n. 12, at 290.

38. I would not try to reconstruct legal pragmatism as a 'comprehensive theory of law', as some theorists, like H. Dagan, do. Dagan argues for the solid 'realist conception of law' (H. Dagan, The Realist Conception of Law (2007)), and S. Perry shows a few general lines of argument in Holmes's view that are able to construe a 'comprehensive theory' similar, to some extent, to the simple theory of T. Hobbes (Perry, above $\mathrm{n}$. 11 , at 160). In each case, I perceive these reconstructions as interesting and proposed in a much more charitable way than the one which I have referred to as an uncharitable critique. and motivations that an official actually has whilst composing a decree, which are not necessarily exhaustive and exactly the same elements that are taken into account by the predicting lawyer. The lawyer and the official have two different vantage points (the lawyer's point of view, who is trying to account for all factors relevant to present a successful prediction, may not account for all the factors that really determine judicial reasoning but only for those that are directly affecting the final opinion; on the other hand, a descriptive theory of adjudication should account for all factors that really influence judicial reasoning, even if they do not determine the final decree, and present the role they play, as well as some explanation of their irrelevance/relevance to the final decree). However, there is a strong incentive to build a complex argument by referring to certain interconnections between these two viewpoints (I suppose that is actually what B. Leiter does $\left.{ }^{39}\right)$. M.G. White notices that the crucial difference relates to the type of theoretical statements (and their justifications) that are produced by each parochial theory. ${ }^{40}$ A lawyer simply defends his prediction by relying on descriptive premises, and thus the prediction is actually an empirical statement (or a conjunction of empirical statements); on the contrary, a judge defends his decree by assuming some legal rules that are not, or at least not exhaustively, empirical statements, and thus, his decree is not generally an empirical statement, but a normative decision, having a 'normative component'. Whether in the second case judges use normative elements (norms, rules, etc.) to create the decree, or only to justify it afterwards, it is of a minor importance, since both mechanisms fall under the overall description made by the empirical, descriptive theory of adjudication. However, the important general point is that none of those mentioned theories is conceptual and makes general claims about 'what is distinctive of any society's legal norms' ${ }^{41}$ They simply state what lawyers and judges do when they either make predictions or decide cases; that is all.

Holmes's pragmatic stance towards the second type of theory can be seen clearly in his works. There are both the descriptive and the normative elements (or both the descriptive and the normative theories of adjudication). On the purely descriptive level, such a theory simply states that there are no essential elements that fall under the description of how judges really think, and that is why the only possible way is to - by the use of the more modern language of Quine - analyse the actual causalnomological connections between underlying situation types and actual judicial decisions (that is what B. Leiter calls 'naturalised jurisprudence'42). By being such a descriptive theory of adjudication, it could probably be classed as scientific and pragmatic but in a very banal sense. Fortunately, Holmes's theory of adjudication also stays in close connection with his thoroughly pragmatic

\footnotetext{
39. Leiter (2001), above n. 12

40. White (2002), above n. 15, at 144

41. Leiter (2001), above n. 12, at 279

42. Ibid
} 
and anti-formalistic attitude towards judicial dissenting opinions and the general role of the judge in the judicial process (and this element contains both simple descriptions of causal connections and much of the elements characteristic of holistic pragmatism program). $\mathrm{M}$. Tushnet calls Holmes a 'great dissenter', meaning that he was not only a great rhetorician but, more importantly, that he had dissented by having such a forward-looking style that was vindicated by history. As A. Mendenhall describes Holmes's approach: 'The language of Holmes's dissents were acrobatic. It acted and reacted and called attention to itself. The more provocative and aesthetic the language, the more likely it was for future judges and commentators to return to the dissent to reconsider Holmes's argument - the more likely that non-law might become law'. ${ }^{43}$

The aesthetics in judicial work, as was also clearly seen by Holmes's successor, B. Cardozo, is a great tool for helping to influence reality in connection with what $\mathrm{J}$. Dewey once called 'intelligence'. ${ }^{4}$ The main elements of judicial tasks are thus twofold: to make an intelligent study of law's history that will illuminate the forces that make the present law thus and so (historical element; the reference to the cultural heritage) and of 'the ends which rules seek to accomplish, the reasons why those ends are desired, what is given up to gain them, and whether those ends are worth the price'. ${ }^{45}$ Both these aspects together lead to the typically liberal and pragmatist conclusion that a judge, whilst deciding the case, should weigh 'considerations of social advantage' whilst paying attention to statistics and economics in particular circumstances, amongst other important social factors (facts). The philosophical background of Holmes and his pragmatist followers can be described as antidogmatic, with an aversion to absolutes and foundationalism, fascinated by contingency and process, putting great focus on different perspectives (perspectivism) and the necessity to relativise each phenomenon to the particular context of analysis and respecting the 'ordinary', common-sensual ordering of things. As such, the local considerations of Holmes, either made from the bad man's/good man's perspective or the descriptive/normative analysis of the way judges think, fall under the holistic program that aims to build an opinion by reference to a cultural/contextual heritage, contemporary beliefs, and scientific and empirical evidence, with a forward-looking perspective towards social change (the latter element is a kind of liberal-pragmatic 'normative punch').

As L. Menand writes: 'It was Holmes's genius as a philosopher to see that the law has no essential aspect'. ${ }^{46}$ The pragmatic character of all parochial theories that

43. Mendenhall, 'Holmes's Dissent', 12 The Journal of Jurisprudence 697, at 680-1 (2011).

44. Cf. J. Dewey, 'Intelligence and Power', The New Republic, 25th April 1934.

45. O.W. Holmes, Jr., 'The Path of the Law', 10 Harvard Law Review 457, at 474 (1897); cf. Haack (2005), above n. 9, at 83.

46. L. Menand, The Metaphysical Club: A Story of Ideas in America (2001), at 339. justify or explain particular decisions or dissents could not then be reconciled into one general theory of law: their locality grants Holmes's theoretical 'consistent inconsistency'. ${ }^{47}$ However, in my opinion, by differentiating certain types of Holmes's theoretical efforts, by setting certain relations between them, and by applying the charity principle, as well as by allowing for some amendments of his work, we can subscribe these efforts under the more general view, namely, the 'holistic pragmatism'. I think this is what White suggests whilst he recommends certain (and obvious) amendments of Holmes's pragmatism that 'suffers from not being explicitly holistic and from being insufficiently mindful of questions surrounding the word "meaning". 48 This can be more clearly seen if we compare the role that conceptual analysis plays in different types of theories, in general theories, and in parochial theories of legal pragmatists like Holmes or Cardozo.

\section{What Does It Mean to Explain a Concept (of Law) in the Pragmatic Sense?}

Sometimes the opposition between legal pragmatism and other legal theories is built upon a reference to the notion of the 'nature' or the 'essence' of law. 'Whether those who hold that statues, reports, and treatises themselves constitute the law have more than a trivial verbal quarrel with Holmes is a nice question. It is customary to construe the debate between legal realists and their more traditional opponents as one between rival definitions of "the same conce between competing attempts to arrive at the "essence of law", but as White notices (and I share that contention with him), 'this is a doubtful construal of the controversy'. ${ }^{49}$ On the other hand, it is true that some of the legal pragmatists' (realists') work was devoted to the attack on the 'conceptualism' of the past, much of which was so aggressive that it degenerated into 'childish nihilism' ${ }^{50}$ But there are also modest views that consciously refer to the conceptual heritage of the past, views that allow for the coexistence of theories from the 'different conceptual levels' - and these moderate views can be connected, although probably to a significant extent implicitly or tacitly, with holistic pragmatism and conceptually reordered under its aegis. At the beginning, it is important to note that to criticise rationalism, as holistic pragmatism does, does not mean

47. Mendenhall (2011), above n. 43, at 683.

48. White (2002), above n. 15, at 152; cf. F. Kellogg, 'Holistic Pragmatism and Law: Morton White on Justice Oliver Wendell Holmes', 40 Transactions of the Charles S. Peirce Society 559, at 560 (2004). The necessity of making additional differentiations and amendments to Holmes's theory is due to the fact that it lacks, as White and Kellogg notice, 'philosophical care'

49. M.G. White, Social Thought in America. The Revolt against Formalism (1976), at 62-3.

50. G. Gilmore, 'Legal Realism: Its Cause and Cure', 40 The Yale Law Journal 1037, at 1038 (1961). 
to reject any concept analysis in its entirety. It can be seen by referring to the most important pragmatic keystone: the Pragmatic Maxim. C. S. Peirce wrote:

It appears, then, that the rule for attaining the third grade of clearness of apprehension ${ }^{51}$ is as follows: Consider what effects, that might conceivably have practical bearings, we conceive the object of our conception to have. Then, our conception of these effects is the whole of our conception of the object. ${ }^{52}$

There are several ways of interpreting this maxim (e.g. as the method of clarifying meaning, as clarifying conception, as the actual process of practical deliberation, and so on). Here, I will limit myself to a few remarks. It seems to be quite obvious that in practical deliberation, we cannot generally avoid concept analysis, and this maxim shows only which concepts (conceptions) are of practical importance. From the vast set of concepts, we can simply cut off ones that do not bear any practical, observable effects. The maxim inevitably forces us to use some kind of scientific test as a proper device to evaluate our beliefs and in that way is connected with 'fallibilism'. All speculative and metaphysical conceptions that cannot be tested scientifically (in the vast meaning of the term 'science'), having no practical bearings, are not worth consideration. Maxim, being as general as it is, is also a simple tool for comparing concepts: two concepts that are supposed to be different, but have the same practical bearings, are actually just the same concept under two labels. The simple framework of the maxim is backed up by the conviction that concepts are labile and are subject to amendment or rejection. But there is always a basic set (or 'heritage' according to Quine and White) of concepts that serves as a starting point for the mechanism of opinion settlement, generally described by the Pragmatic Maxim. This maxim is a 'method or approach to philosophical questions focused on pragmatic consequences, not a body of philosophical doctrine'. ${ }^{5}$ This general interpretation allows for both the Peircian understanding of the 'pragmatic' following Kantian 'pragmatische' (experimental) and the Jamesian one that focuses on praxis (action as opposed to theory) ${ }^{54}$ I think it is now easy to see the parallel between Holmes's presentation of the 'prediction theory' and

51. Peirce's distinction between the three grades of clarity of concepts (the first grade, an unreflective grasp of the concept in everyday experience; the second grade, a definition of the concept; the third grade, the Pragmatic Maxim) reveals the difference between 'having a merely verbal understanding of a scientific concept and having a seriously knowledgeable grasp of what it involves' (S. Haack, 'The Growth of Meaning and the Limits of Formalism: in Science and Law', 29(1) Analisis Filosofico 5 , at 11 (2009)). This method of concept clarification is especially useful in legal science, where the growth of meaning can advance rapidly in a short period of time.

52. Peirce (1878), above n. 2.

53. Haack (2005), above n. 9, at 76 .

54. On different meaning of 'pragmatic' in pragmatists' works, see, for example, Haack (2005), above n. 9.
Peirce's general statement of the Maxim ${ }^{55}$ : the suffering, the potential harm, or gain caused by the judicial decision, predicted by a lawyer, is all we can measure empirically. However, the simple prediction theory has never been claimed to be an exhaustive, general theory of law, and as I showed above, it is not the only theory that Holmes himself explicitly developed. On the contrary, Holmes stressed that his theory was local (or 'parochial' according to White); it focused on one, particular, legal system and did it from a very specified perspective that of an operative lawyer. However, S. Haack persuasively suggests that Holmes's philosophy is much more sophisticated than the label 'prediction theory' implies, and she shows how The Path of the Lam leads from a couple of cynical statements about the concept of legal obligation that actually are 'the mundane specificities of the working attorney' at the beginning of the lecture, to the end, where we can see the great 'intellectual aspirations of the legal theorist'. ${ }^{56}$ To a large extent she is right, but she builds that argument extensively by showing some general strands in Holmes's thinking and cites many of his other works, decisions, and dissents as evidence. I think the way in which such a conclusion can be reached is much easier, as far as we focus on the meaning of conceptual analysis that was conducted by Holmes himself in connection with many, maybe not perfectly clearly distinguished but nevertheless present, theoretical points of view of law that he, at least implicitly, proposed. And in all these mini-theoretical cases, the pragmatic maxim can be in use.

Although Holmes refused to use the label 'pragmatism', he may well be called a pragmatist, simply because 'he treats rules and standards as necessarily communal and objective, and because he describes the legislative function performed by the community in determining and applying law. These notions are fundamentally Peircian'. ${ }^{57}$ And this is characteristic not only of The Path of the Lam but also of other major works, including The Common Lam which 'felt the necessities of the time, the prevalent moral and political theories, intuitions of public policy, avowed or unconscious' to be the communal, objective standards by which every law is determined, staying in contrast to private and subjective (Holmes called it 'moral') standards. ${ }^{58}$ The distinction, developed in that publication, between external (objective, communal) and internal (subjective, moral) standards can be easily seen in The Path of the Lam, where Holmes presents a strong claim concerning the separation of law and morals. It is, however, crucial not to confuse this claim with the positivist separation thesis. As Kellogg notices: 'What Holmes meant in eschewing moral language was not an ontic separation but a fallibilist insight, in effect competing principles can generally be found on both

55. And I leave open the historical controversy over whether it was Peirce who inspired Holmes or the reverse (during their activity in the Metaphysical Club the end of the 1860s and the beginning of the 1870s).

56. Haack (2005), above n. 9, at 82.

57. Note: 'Holmes, Peirce and Legal Pragmatism', 84 (5) The Yale Law Journal 1123, at 1125 (1975).

58. Note (1975), above n. 57, at 1127 
sides of controversial case, and moral argument from them amounts to "hollow deduction from empty general propositions". 59 According to the Pragmatic Maxim, in order to be meaningful, a concept must have practical consequences that are both public and communal (due to Peirce's critique of introspection that stays in connection with his anti-Cartesianism), and Holmes's basic distinction between internal and external standards 'responds to the same philosophical impulse that led Peirce to say that all knowledge of our psychological states is derived from observation of public facts' ${ }^{60}$

What is more, in addition to this parallel between the pragmatic methods of Peirce's and Holmes's views of law, there are deeply holistic roots to Holmes's thinking that can be found in the philosophy of C. Wright who taught him, according to Holmes's own words, that he 'must not say necessary about the universe, that we don't know whether anything is necessary or not', 61 and we can only bet on the behaviour of the universe (Holmes discussed the notion of bet ability being a form of predictability). Wright argues for the holistic account of a socially rooted development of perception, cognition, and language, being anti-Cartesian and pro-Darwin all at the same time. This may stand as a real historical background of Holmes's holistic thinking. ${ }^{62}$

The problem that triggered so much of the unfriendly critique against the 'predictive theory of law' was that Holmes speaks very loosely of meaning. In The Path of the Law, he concentrates on the perspective of a 'billpaying client', who 'does not pay a lawyer to make disputable philosophical claims about general legal concepts'. ${ }^{63}$ However, unfortunately, Holmes seems to treat 'the prediction (prophecy)' and 'the law' as synonyms. That causes a lot of confusion if one does not recognise the two features characterising Holmes's writings. First, Holmes explicitly stated his own view about 'meaning', whilst he said that the word 'law', as many other words, may be properly used in many different ways. '[A] word is not a crystal, transparent and unchanged; it is the skin of a living thought and may vary greatly in color and content according to the circumstances and time in which it is used'. ${ }^{64}$ Second, as we can see, Holmes used a very artistic language, full of cynical, sharp metaphors and epigrams (and that style remained characteristic of further pragmatists' legal writings). As I indicated earlier, the 'bad man's point of view' is only a heuristic device of an operative lawyer who does not assume any strict connection between law and morality. This is, however, only one of many ways in which one can describe law or theorise about law. Besides the bad man's point of view, we can distinguish also (1) the 'good man's point of view', from which all the possible positive effects of the decision other than fear and harm are evaluated (that perspective, however, could be inclu-

59. Kellogg (2004), above n. 48 , at 565.

60. Note (1975), above n. 57, at 1132.

61. Kellog (2004), above n. 48 , at 562

62. Kellog (2004), above n. 48, at 563.

63. White (2002), above n. 15, at 137.

64. O.W. Holmes, Jr., U.S.S.C., Towne v. Eisner 245 (1918) 418, at 425. ded under the aegis of the 'predictive theory' by a simple but 'charitable' amendment of what Holmes originally wrote); (2) the reconstructed officials' point of view, ${ }^{65}$ which amounts apparently to a descriptive theory of adjudication sensu $\operatorname{largo},{ }^{66}$ i.e. 'a theory about what it is that judges really do when they decide cases' (this point of view is characteristic of efforts made by legal realists; it is different from the bad man's and the good man's points of view, because it does not fall under the aegis of the 'predictive theory', as far as no judge would predict his own decision - he would rather refer tacitly or explicitly to some legal theory to construe it ${ }^{67}$ ); and (3) the general jurisprudential point of view that aims at analysing important legal concepts; it divides into at least two types of the theory: one that allows for either a methodologically external or detached point of view (e.g. legal positivism) and the other ones that claim that it is impossible to separate moral valuations from conceptual analysis and social-phenomena description ('law as integrity', ius-naturalism).

There are two important things I want to stress in the context of this differentiation: 'conceptual gradualism' and the 'parochial-general discrimination'. First, the requirements of scientific precision rise gradually as we move from the theory of the first type (both good man's and bad man's theories, where the pragmatist razor cuts off all concepts that have no experimental bearings but, on the other hand, allows for a very labile use of certain concepts) towards the theory of the third type that focuses on deeper analysis of the concepts that are supposed to be at least temporarily settled (rigid concepts are much easier to analyse, either by logical or non-logical methods). Second, there is a substantial difference between theories that are fully fledged pragmatic enterprises such as the predictive theory (that are parochial, relativised to space and time) and more general theories that focus on the way in which a legal official performs so-called reasoning according to law or even the most general theories that fall under the aegis of 'general jurisprudence' that aim to give detailed analysis of the most general, universal legal concepts ('reasoning about law'). The most important feature of that differentiation is that the former theories must always presuppose, at least tacitly, some of the important assumptions of the latter that are both more general and usually more detailed (at this general level).

65. The relation between the reconstructed officials' point of view and the apparent, institutional officials' point of view is such that the former includes the latter (but not vice versa). The latter involves primarily general, mutual officials' beliefs about the way they perceive their own institutional enterprise. In other words, the latter point of view comprises of how officials think about what they do (like construing a 'normative decision' and how they can justify it), but do not necessarily involve the description of what they actually do (which the former view includes).

66. In contrast, the apparent, institutional officials' point of view mentioned in the footnote above, being in fact a description of the shared theory of how should judge justify her decision as 'normative' or 'binding' in context of existing legal institutions, can be dubbed a 'theory of adjudication sensu stricto'.

67. Leiter (2001), above n. 12, at 279 
The conceptual analysis is characteristic of the broadest theories of the latter type. These theories are general, and their main task is, as in case of legal positivism, to explain the main concepts that reflect the fundamental features of societies. J. Raz once stated that 'We do not want to be slaves of words. Our aim is to understand society and its institutions', ${ }^{68}$ and the proper tool to do that, to reveal the most important and universal features of law, is conceptual analysis. B. Leiter notices that this kind of analysis has two important features. ${ }^{69}$ First, the analysis aims at describing law and its institutions as conceptually different from other types of social/cultural institutions. Such an idea stays in close relation to socalled Autonomy Thesis (a conceptual thesis developed in part by G. Postema ${ }^{70}$ ) and has its empirical counterpart in the Limited Domain Thesis. ${ }^{71}$ Both those theses describe (or refer to) the criteria of legality, but the first does it on the highest, most conceptual level; the second thesis is merely an observational, factual statement. The second is the role, presumably distinctive, that law plays in practical reasoning of officials and citizens. This thesis is supposed to explain the normative, reason-giving character of law, namely, how law purports to guide anyone's conduct. Those two points, however different, are usually combined on the grounds of conceptual, general jurisprudence. Positivists think that the reason givingness of law is strictly connected with the idea that legal reasons are autonomous reasons, and non-positivists, like Dworkin, argue that the normative character of law is strictly connected with law being morally valid and thus nonautonomous. However, I am not going to describe this discussion in detail here.

Instead, I would like simply to state that in the case of legal pragmatism, neither of these two points is at stake. Legal pragmatists, with the prime example of Holmes, just do not care (in the sense: they do not primarily care) about concepts that are discussed by academics. They do not care how it happens - although they may consider such theorising as a great intellectual play - that people's behaviour is governed by reasons delivered by the law nor why and in what circumstances law has authority and whether it is autonomous or not. On the contrary, the conceptual scaffolding of legal pragmatists is a very simple one and can be reduced to the use of scientific methods, as simple as possible, to build an opinion (a holistic conjunction of beliefs) that would either help to predict a decree for a paying client or to justify a decree in certain a political and cultural context. Such efforts, however, do not supplant the need of using more general, conceptual schemes that would account for a 'comprehensive theory of law'.

68. J. Raz 'Legal Positivism and the Sources of Law', in J. Raz (ed.), The Authority of Law (1979) 37, at 41.

69. Leiter (2001), above n. 12

70. G. Postema 'Law's Autonomy and Public Practical Reason', in R.P. George (ed.), The Autonomy of Law: Essays on Legal Positivism (1996) 79.

71. F. Schauer, 'The Limited Domain of Law', 90 (7) Virginia Law Review 1909 (2004)
Nevertheless, the relation between the most parochial predictive theory, the empirical theory of adjudication, and a general theory of law is as follows. The predictive theory must assume at least some kind of an empirical theory of adjudication, because an operative lawyer must know what rules, facts, reasons, and motivations could be applied or referred to by a judge who is composing a decree. A lawyer's concern is about 'predictions of the incidence of the public force through the instrumentality of the courts', ${ }^{72}$ which are what a bad man pays a lawyer to make. To make such predictions, a lawyer must know much more than only the set of legal rules that the judge is likely to apply, but amongst these are quite simple concepts like the concept of the authoritative judge. As White argues, the lawyer and his client are not interested in 'useless quintessence of all legal systems', and Holmes and other legal pragmatists do not define the words 'judge', 'authority', or 'the law'; they simply "know the judge [and respect "authority" or "the law/statute"] when they see one'. So, on this level, 'the judge' can be defined ostensively, but this also demands some deeper presupposition of the 'authority' that grants the judge the power to resolve cases. ${ }^{73}$ Furthermore, any kind of a theory of adjudication must presuppose - and this is quite suggestively elaborated on by Leiter - 'a non-skeptical account of legality'74 and must, to some extent, rest on some conception of a legitimate legal authority. Only in these circumstances could the court decision be 'justified', or even 'understood', as a decision of a court. It is so because no one is obligated to act with simple lawyers' prophecies or even empirical statements about the way in which judges are reasoning. All parochial theories need some more general view as their background assumptions.

What is interesting is that Holmes himself seems to agree with this notion when he claims that we still 'have too little theory than too much', ${ }^{75}$ although he does not appear to be developing, in The Path of the Lam, a theory of a comprehensive type. Nevertheless, it seems to be obvious that Holmes, both in this lecture and in other writings and rulings, usually introduced more general, typically pragmatist, methodological precepts of empirical sciences. The arguments presented by White, and comments given, for instance, by F. Kellogg, suggest that he would probably enthusiastically meet the amendments and clarifications made from the perspective of a unifying but interdisciplinary holistic pragmatism. $^{76}$

White notices that Holmes fails to discuss the concept of law or the concept of legal authority at a greater length, and he thinks, like Leiter, that there must have been

\footnotetext{
Holmes (1897), above n. 45, at 457.

White (2002), above n. 15, at 131.

Leiter (2001), above n. 12

Holmes (1897), above n. 45, at 476.

76. Kellogg writes: '[l]f Holmes had lived just 25 years longer to read White's Toward Reunion in Philosophy (1956), especially the passage on pp. 161-2 in which White compares philosophical definition with the process of legal adjudication, he would have uttered the famous 'Good for you!' with which he welcomed an excellent argument in the Supreme Court' (Kellogg (2004), above n. 48, at 565).
} 
some deeper positivistic assumption about the nature of law (some kind of a Social Fact Thesis) that would enable parochial theories to work. However, S. Haack writes: 'Holmesian argument seems, as it stands, covertly to presuppose the kind of purely abstract and essentialist philosophy of law that he officially, and in my opinion - rightly - eschews'. ${ }^{77}$ The question now is whether every general, jurisprudential theory of law must be 'essentialist' in the sense that it would reveal 'the very nature of law'? I think that we can answer this question in two different ways, but having the same effect. Firstly and more commonly, there appears a discrimination between two types of a general, conceptual analysis: ambitious and non-ambitious conceptual analysis (in different terminology: immodest and modest conceptual analysis ${ }^{78}$ ). The point is that the non-ambitious (modest) conceptual analysis strives at the most accurate translation ('paraphrasing', in Quine's words) and rational change (in light of particular, empirical evidence) of the 'folk theory' of certain things, whilst the ambitious (immodest) analysis strives to determine the way things really are. For example, Hart's conceptual analysis, being an enterprise in 'descriptive sociology', is probably best understood as a non-ambitious (modest) analysis, because it tries simply to present the way in which some constellation of basic legal concepts (it is a kind of legal-theoretical vocabulary that covers both actual and possible cases of concept application) is made true by another, more basic vocabulary, rooted in the folk theory of law. So, in its modest type, the conceptual analysis role is that, by Jackson's own words, 'of addressing the question of what to say about matters described in one set of terms given a story about matters described in another set of terms. Conceptual analysis is not being given a central role in determining the fundamental nature of our world; it is, rather, being given a central role in determining what to say in less fundamental terms given an account of the world stated in more fundamental terms'. ${ }^{79}$ Modest analysis serves to 'elucidate concepts by determining how subjects classify possibilities, and [Jackson] emphasises that conceptual analysis is an hypothetical-deductive exercise'. ${ }^{80}$ If that type of analysis, characteristic of the mainstream activity of analytical jurisprudence, means actually 'seeking the hypothesis that makes best sense of a person's responses to possible cases, taking into account all the evidence', ${ }^{81}$ that seems at least compatible with pragmatic fallibilism and holism more generally. And, of course, in this case, searching for a conceptual 'quintessence of law' does not necessarily mean searching for a 'nature of law' in any of

77. Haack (2005), above n. 9, at 88

78. F. Jackson, From Metaphysics to Ethics (1998); for the legal context see V. Rodriguez-Blanco, 'A Defence of Hart's Semantics as Non Ambitious Conceptual Analysis', 9 Legal Theory 99 (2003).

79. Jackson (1998), above n. 78, at 44 .

80. Rodriguez-Blanco (2003), above n. 78, at 104

81. Jackson (1998), above n. 78, at 36; cf. Rodriguez-Blanco(2003), above n. 78 , at 105 essentialist meanings of that term. ${ }^{82}$ So, this general stance can be reconciled with harsh pragmatists' negative response to any 'essentialist' (and in this ambitious sense 'conceptual') theory of law. Had Holmes lived long enough he could be really interested in such a nonambitious reading of Hart's theory. Nonetheless, he would probably be very disappointed by its further essentialist developments, to which Hart himself contributed, for example, by making reference to 'descriptive sociology' and suggesting that law is exclusively and essentially determined by special, foundational social facts. ${ }^{83}$ Embracing a modest analytic apparatus allows to read Hart in a non-essentialist mode, however, at the expense of loosing some features of the broadly 'Hartian' theory that has been extensively discussed through the years.

Secondly, it seems to be quite certain from the whole of White's enterprise in the philosophy of culture that when he criticises Holmes for being 'too parochial' and says that his theory must presuppose the more general theory of legal authority (like the Hartian one), he does not think of such a theory as foundationalist or essentialist. He is a holistic pragmatist, so far! White reads Hart modestly, in the way described above. That would mean that the holistic pragmatism could be perceived as a background for a general theory of law, as well as for many parochial theories that tacitly presuppose that one. It would be very interesting to discuss how both general and parochial theories of law apply the holistic pragmatist's machinery and what the limits are of such an application.

\section{Epilogue: Legal Pragmatism as an 'Independent Theory of Law'?}

When discussing O. W. Holmes's answer to the question What constitutes the law?, M. G. White underlines the simple fact that Holmes's inquiry did not focus on developing the concept of law. White argues: 'Holmes said little in The Path of the Lam about the notion of legal authority, perhaps because he was interested not in what he called a "useless quintessence of all legal systems" but in "an accurate anatomy of one". 84 Such ambition (or lack of ambition) is characteristic of many pragmatic enterprises in the legal field. However, many legal philosophers who aim at revealing the very 'nature of law' (or 'the concept of law' as H. L. A. Hart did) try to interpret Holmes and other pragmatists as offering a

82. Actually, there is a very simple way to show that the question from The Path of the Law, namely, the question What constitutes the law? is not a general jurisprudential question. The 'the' prefix suggests the local character of it. On the contrary, Hart and Dworkin ask What is law? and the lack of 'the' prefix suggests the most possible general sense of their inquiry.

83. That puts the whole Hartian discourse on the 'metaphysical track'

84. White (2002), above n. 15, at 130. 
competitive view to their own. As I have (at least partially) tried to demonstrate, this is wrong and oversimplifies the problem. Holmes, and other legal pragmatists, could have held many parochial accounts of local legal concepts at the same time, being 'consistently inconsistent'. On the other hand, we can differentiate between very parochial, modestly parochial, and general theories of law. Parochial theories must be partially presupposed by some concepts of a more general provenience and thus be at least partially independent ${ }^{85}$ from the general ones. The independence in the above-mentioned sense is not full; thus, probably it would be more proper to speak of each and every legal pragmatist effort as an 'underdetermined theory of law'. I would not use the word 'parochial' nor the word 'local' to describe the legal pragmatists' approach generally, but I think that particular divagations could be treated as tiny, 'parochial' theories built from a local perspective, but by the use of the same 'holistic machinery' (that grants their general consistency). Moreover, I think that there could be many more local perspectives than the ones legal pragmatists have yet presented. What is important is that they all tend to fall under more general methodology, namely, holistic pragmatism, and hence they can coexist conceptually with some other, more general, theories that also accept, or at least do not deny, that metaphilosophical position.

If one does not read the aims of the theoretical background accurately, she/he may use the methodological objection I introduced in the beginning incorrectly and in consequence, think that the 'premises of the theory are shaky' and thus its 'promises - overstated'. ${ }^{86}$ We can see that there need not be any conflict between conceptual analysis of a moderate (non-ambitious) type and legal pragmatist efforts. Moreover, it seems to be quite promising to use the scaffolding of holistic pragmatism to both evaluate existing general legal theories and to explore a general theory of law that would be quite consistent and pre-suppositional for all parochial theories of law, the ones in which legal pragmatists are most interested. After all, M. White's holistic pragmatism is probably the best of all efforts to unify pragmatic philosophy. ${ }^{87}$ It fits the metaphor of G. Papini who once compared pragmatism to a hotel where all the guests pass through the same corridor, but each works alone in his

The independency claim I am making here is a claim about the relation between theories that fall under different degrees of generality. It is not the claim about the rigid independency, or even autonomy, of different (at face value) cultural domains (science, law, art, ethics), because according to the metaphilosphical position of holistic pragmatism, they simply could not be separated. Parochial theories are not themselves instances (tokens) of these more general theories. Rather, as I tried to show, parochial theories in fact work in virtue of some background theories (e.g. general theory of 'authority'). The holistic framework is the most general on the scale.

86. Gilmore (1961), above n. 50, at 1037.

87. Kellogg (2004), above n. 48; Pihlström (2011), above n. 15 own room ${ }^{88}$ and as such, stands as a prime candidate for the resolution of apparent confusions about legal philosophy as well.

88. 'As the young Italian pragmatist [Giovanni] Papini has well said, [pragmatism] lies in the midst of our theories, like a corridor in a hotel. Innumerable chambers open out of it. In one you may find a man writing an atheistic volume; in the next, someone on his knees praying for faith and strength; in a third a chemist investigating a body's properties. In a fourth a system of idealistic metaphysics is being excogitated; in a fifth the impossibility of metaphysic is being shown. But they all own the corridor, and all must pass through it if they want a practicable way of getting into or out of their respective rooms' (James, above n. 3, at 32; cf. S. Haack, 'The Pluralistic Universe of Law: Towards a Neo-Classical Legal Pragmatism', 21(4) Ratio Juris 453, at 454 (2008)). 